\title{
GILUMINIŲ SAITŲ NAUDOJIMAS KŪRYBINĖJE ISTORIJOS STUDIJŲ VEIKLOJE
}

\author{
Doc. dr. Arūnas Vyšniauskas \\ Generolo Jono Žemaičio Lietuvos karo akademija
}

\begin{abstract}
Anotacija. Atkreipiamas dèmesys $i$ per pastaruosius 15 metu pasikeitusias pasaulinio žiniatinklio sąlygas (Web 2.0), kurios verčia ieškoti nauju mokymo(si) ir studijavimo sprendimu: komunikaciniu skaitmeniniu mokymosi platformu kūrimas, postskaitmeninio vadovèlio idèja, socialiniu tinklu galimybiu išnaudojimas, kūrybiška eklektika ir kt. Straipsnyje iškeliama giluminiu saitu reikšmè, didinant istorijos studiju medžiagos interaktyvinimo galimybes. Pateikiami hipertekstu pavyzdžiai, kuriuose derinami paprastieji ir giluminiai saitai, nagrinejant tanku istorija kaip karybos istorijos dali, siejant ja su dabarties karinemis aktualijomis. Teikiami praktiniai patarimai, darant giluminius saitus, taip pat naudojant tinklalapius su viki funkcionalumu. Rekomenduojama plèsti studentu (kariūnu) rašto darbu ir stiliu juvairovę, atsižvelgiant ị istorijos perteikimo ịvairialypius poreikius, savireguliacinio mokymosi perspektyvas, mokslinès prozos kūrimo įvaldyma ir humanitariniu mokslu dvasia.
\end{abstract}

Pagrindiniai žodžiai: saitas, giluminis saitas, karybos istorija, tankai, vadovèlis, vikis, Web 2.0, istorijos studijos.

\section{Ivadas}

Lietuvišku terminu „saitas“ įvardijame tai, kas anglų kalboje vadinama hyperlink, o sutrumpintai - link. T. y. hipertekste esanti nuoroda, turinti matomą dali ir po ja paslèptą komponentą - nurodomo objekto adresą (Dagienè, V., Grigas, G., Jevsikova, T., 2008: 413). Lietuviškai vartotinas ir hipersaito terminas, tačiau „saitas“ yra trumpesnis žodis, dèl to - patogesnis. Paprastujų saitų ir giluminių saitu problematika lietuviškoje akademinèje literatūroje jau yra nagrinèta teisiniu požiūriu - žvelgiant per intelektinès nuosavybès prizmę autorių teisių aspektais (Morkytè, E., 2007).

Šiame straipsnyje siekiama analitiškai aptarti saitų kūrimą ir hiperteksto komponavimą edukologiniu požiūriu, atskleisti giluminių saitų reikšmingumą bei perspektyvas, kūrybiškai studijuojant karybos istoriją ir kitus kariūnams artimus dalykus. Apie giluminius saitus istoriko kūrybinejje veikloje jau teko skaityti pranešimą 2012 m. rudenị Lenkijoje, Liubline, Marijos Kiuri-Sklodovskos universitete vykusioje mokslinejje konferencijoje „Multimedija ir istoriniai šaltiniai mokyme 
ir tyrimuose“. Pagal pranešimą parengtas akademinis straipsnis pasirodè $2015 \mathrm{~m}$. išleistame mokslinių straipsnių rinkinyje lenkų kalba. Jame suformulavau naują gebèjimą, svarbų istorikų kūrybinei veiklai. Jis skamba taip: „Kūrybiškas ir giluminis saitų internete darymas, ịvairius šaltinius ir istorines informacijas tarpusavyje susiejant naujai ir originaliai, yra naudingas istorikui gebėjimas“ (Vyšniauskas, A., 2015: 306).

Toliau, perimant kai kurias lenkų kalba paskelbto straipsnio mintis, bus pateikti konkretūs pavyzdžiai istorine tematika lietuvių skaitytojams. Visų pirma, tokie, kurie susiję su karybos istorijos dalykais. Tikimès, kad tai padès atkreipti dėmesị ị interneto technologijų efektyvesnị panaudojimą militarinès istorijos studijoms ir mokymuisi. Kodèl tai galètu pasirodyti svarbu?

Teorinès literatūros apie studijų modernizavimą, projektų metodą ir pan., iš tikrujų, yra nemažai, tačiau trūksta praktinių patarimų, ką ir kaip daryti, ko reikia siekti, kaip turi atrodyti sukurtas individualaus ir kolektyvinio mokymosi kūrybinis rezultatas - produktas. I tai atkreiptas dèmesys šių eilučiu autoriaus mokymo metodikos knygoje apie istorijos studijų modernizavimą (Vyšniauskas, A., 2002). Ji buvo įvertinta Švietimo ir mokslo ministerijos premija už mokslo populiarinimą, sulaukè palankių recenzijų akademinèje spaudoje. Toje knygoje pažymèta interneto reikšmè studijų modernizavimui, tačiau reikia nepamiršti, kad pasaulinis žiniatinklis World Wide Web, atvèręs galimybes laisvai ir momentaliai gauti ịvairialypę informaciją skaitmeniniu formatu bet kuriame pasaulio taške su internetine prieiga, knygos pasirodymo metu, t. y. 2002 m., užbaiginèjo tik pirmajj savo gyvavimo dešimtmetị.

İžengus į XXI amžių, netrukus prasidejo naujos kartos interneto fazè, sutrumpintai įvardijama Web 2.0. Šis terminas pirmą kartą buvo viešai panaudotas $2003 \mathrm{~m}$., bet dabar antrosios generacijos pasauliniam žiniatinkliui apibūdinti jau yra naudojami ir „socialinių medijų“, „socialinių tinklų“ terminai, mat esminiu bruožu internete tapo perẻjimas nuo statiškų HTML tinklalapių prie labiau dinamiškų, sudarant galimybę žmonėms daugiau tarpusavyje komunikuoti, bendradarbiauti, keistis informacija tinkle, naudotis įvairiais tinkliniais servisais. Vienu iš požymių tapo interneto vartotojų generuojamas turinys. Wikipedia, YouTube, Facebook, Instagram ir kiti atsiradę internetiniai žinių, naujienų, nuotraukų, filmuotos ir kitokios medžiagos dalijimosi kanalai atvėrè naujas sąlygas ir galimybes, kurias, daugelio supratimu, vertètų efektyviau išnaudoti studijose.

Reaguodamas ị vykstančius pasikeitimus, ieškojau naujų istorijos studijavimo būdų ir metodų - šioje srityje igyta tam tikra asmeninè dėstytojo patirtis. Buvo sekamos mokslinès ir metodinès literatūros naujienos, atitinkami žiniasklaidos pranešimai, interviu su patyrusiais istorikais. Žiniasklaidoje užtinkame istorijos dèstytojų vertingų pasisakymų, tačiau grynai akademinès literatūros apie universitetinę didaktiką istorijos studijų srityje randame ne taip jau ir daug. O jei randame, tai joje dažniausiai aprašinèjami asmeniniai dėstytojų potyriai, ịdomios situacijos, kilusios problemos ir pan. Vadinasi, konkrečių atvejų analizè, asmeninès patirties pertei- 
kimas, pasidalinimas ir ịžvalgos bei apibendrinimai yra metodinè vertybė per se. Tą, pavyzdžiui, galima konstatuoti, paminint prieš dešimtmetị Vokietijoje išleistą teminį straipsnių rinkinį, skirtą projektų metodui istorijos užsièmimuose (Lässig, S., Pohl, K. H. (Hrsg.), 2007). Dalis rinkinio autorių buvo aukštujų mokyklų dèstytojai - istorikai, atskleidę gerosios praktikos pavyzdžių, bet kartais nenutylëję ir nepasisekusius dalykus.

Tikiuosi, kad šiame straipsnyje aptariama giluminių saitų problematika, pateikiami keli originalūs hiperteksto pavyzdžiai ir praktiniai patarimai, taip pat naujo tipo vadovèlių kūrimo globalinių tendencijų išryškinimas padès ne tik istorikams, bet ir kitų sričių dèstytojams kūrybiškai pasinaudoti Web 2.0 teikiamomis galimybėmis, įtraukiant besimokančiuosius ị projektinę veiklą, naudojant mokymosi platformas su viki funkcionalumu. Straipsnio pabaigoje bus pasidalinta įžvalgomis ir tam tikrais apibendrinimais apie galimas tolesnes studijų modernizavimo ir optimizavimo kryptis, žvelgiant iš humanitarinių mokslų atstovo perspektyvos.

\section{Kūrybiška eklektika istorijos pažinimo tikslais}

Giluminiais saitais laikomas toks hipersaitų kūrimo būdas, kai sąsaja internete dedama ị konkretų internetinio resurso elementą. Anglų kalboje tai ịvardijama žodžiais deep links arba sudurtiniu terminu deep-links, o giluminių saitų kūrimas vadinamas deep linking. Jis suteikia galimybę tiesiogiai pakliūti ne tik ị dokumentų atskirus failus, bet net ir atskirus dokumento puslapius arba grafinius atvaizdus, tam tikras audio failų vietas, filmuotos medžiagos atskirus momentus, kadrus ir t. t. Tokie saitai ženkliai pagerina tradicinio istorijos pažinimo ir perteikimo galimybes. Galima sakyti, kad pasaulinis žiniatinklis ir susikūre kaip hipersaitų sistema, tačiau dabartiniais laikais atsirado žymiai daugiau galimybių rasti medžiagos, ją atsirinkti ir kūrybiškai susieti. O jei priimsime tai, ką sako šiuolaikinè vokiečių istorikè Ana Veronika Vendland (Anna Veronika Wendland), - ,geri istorikai yra kūrybiški eklektikai“ (Вендлянд, А. В., 2012).

Iliustruotų informacinių koliažų metodika, kurią esu pateikęs minètoje 2002 m. metodikos knygoje, suskamba tokiomis sąlygomis dar aktualiau, mat jei vaizduojamajame mene koliažas įteisino tam tikrą eklektiką, priklijuojant plokštumoje heterogeniškos prigimties dalis, tai informaciniame koliaže žinios pateikiamos, atsirinkus jas iš ịvairiausių resursų ir atskiras dalis „suklijuojant“" i rišlų tekstą su iliustracijomis. Anksčiau tai buvo daroma popieriniuose variantuose, o dabar, dirbdamas su studentais, pastaraisiais metais labiau orientuojuosi ị skaitmeninị formatą. Juk fiksuotoms versijoms studento rašto darbas, padarytas MS Word formatu, nesunkiai konvertuojamas į PDF failą, kuri patogų pateikti virtualioje mokymosi aplinkoje. 
1.1. Saitai vikiuose. Nors kaip vartotojas esu įvaldęs interneto puslapių kūrimą, o saitu kūrimas čia yra natūralus dalykas, tačiau pastaraisiais metais nemažai naudojausi viki galimybėmis, kurios dar labiau techniškai supaprastina turinio medžiagos pateikimą ir kolaboratyvinę veiklą. Teko kaip kūrējui naudotis The Wikimedia Foundation operuojamomis platformomis: Vikipedija, Viki knygomis, Vikiteka. Nors turiu Facebook paskyrą, pripažindamas pastarojo socialinio tinklo potencialą, juo vis dèlto naudojuosi mažai, tačiau nuo $2014 \mathrm{~m}$. susidomejjau Google puslapiu (Google Sites) teikiamomis galimybėmis, mat čia galima buvo itraukti studentus kaip registruotus vartotojus ir bendromis pastangomis kurti studijoms naudingą turini, naudojantis viki funkcionalumu. 2014-2015 m. m. ir 2015-2016 m. m., dèstydamas VU Filologijos fakulteto Skandinavistikos centro studentams, Google puslapių platformoje inicijavau viki projektą, kurị pavadinau Skandevu. Jis prieinamas tik registruotiems vartotojams, o jame sudèta mano ir studentų sukurta medžiaga, leidžianti geriau pažinti Šiaurès šalių geografiją, kultūrą, istoriją, kasdieni gyvenimą ir t. t.

2016-2017 m. m., pradejjus dirbti Generolo Jono Žemaičio Lietuvos karo akademijoje, remiantis Google Sites galimybemis ir naudojant tarnybinio el. pašto prisijungimo paskyrą, buvo sukurtas vikis „Karybos istorija“, prieinamas registruotiems vartotojams - kariūnams. Vikių panaudojimas karybos dalykų gilesniam pažinimui ir kūrybinio turinio kūrimui nèra naujiena - kaip pavyzdi galima nurodyti Military Wiki. Tai didžiausia online enciklopedija karine tematika anglų kalba, prieinama laisvai. Šiuo metu ten yra virš 200 tūkstančių straipsnių, o minètas vikis „Karybos istorija“ - lietuviškas, prieinamas tik registruotiems vartotojams. Be to, čia galima rašyti nebūtinai sausu enciklopediniu stiliumi.

Kai kurie pastoviai atnaujinamo vikio „Karybos istorija“ tinklalapiai igijo pakankamai brandžią kondiciją, tinkamą tolesniam studijavimui ir medžiagos tobulinimui, taip pat ir kaip metodiškai vertų demesio tekstų pavyzdžių publikavimui. Pateiksiu keletą fragmentų iš sukurto viki puslapio „100 metų tankų istorijos“. Naudoti tiek ịprasti, tiek giluminiai saitai. Atrodo, kas čia tokio? Juk Google paieškos sistema apie tankus pagal raktinius žodžius duoda gausybę resursų. Vis dèlto internetinès paieškos robotai resursus pateikia atskirai, nesusiedami jų tarpusavyje literatūriškai ir konceptualiai. Bet tai, ko nesugeba robotai, gali padaryti žmonès! Žemiau pateikiamame tekste nuorodos ị internetinius resursus yra integruotos ị rišlų tekstą, kuris gali būti traktuojamas kaip vadovèlinio teksto, skirto tankų istorijai, dalis.

1.2. Šimtametė tankų istorija. Spausdintame įrèmintame tekste internetiniams adresams nurodyti panaudota išnašų funkcija. Išnašos pateikiamos straipsnio pabaigoje. 


\section{Pirmieji tankai}

Britai ir prancūzai - tankų pionieriai. Tankai pirmą kartą pasaulio istorijoje buvo panaudoti 1916 m. rugsėjo 15 d. Somos mūšyje. Tai buvo britų tanko modelis Mark I. BBC interaktyvi animacija: Weapons of War: Mark 1 Tank $^{1}$. Atkreipkite dèmesị, kad pirmasis mūšyje panaudotas tankas buvo rombo formos, o vikšrai - per visą korpuso aukštį. Taip britų konstruktoriai sieke išvengti galimo vikšru nukritimo mūšio metu. Vikšrai nekrito, bet gremėzdiškas tankas buvo mažai manevringas. Paraleliai savo tanko modelị kūrè ir prancūzai, jų dizainas buvo kitas. Pirmuoju moderniu tanku laikomas būtent prancūziškasis Renault FT $^{2}$. Nesunku suprasti, kad vèliau tankų gamyboje pasaulyje įsigalèjo prancūziškojo tipo konstrukcija, kurios esmè - ant vikšrinès platformos sumontuotas bokštelis su patranka. Tuo keliu nuejjo ir vokiečių bei rusų konstruktoriai.

Vokiečiai kūrẻ savo tankus. Vokiečiai pirmajị tanko prototipą pasigamino $1917 \mathrm{~m}$., $1918 \mathrm{~m}$. turèjo pagaminę tinkamų karinėms operacijoms A7V modelio 20 tankų, kas buvo mažai, palyginus su britais ir prancūzais, tačiau vokiškasis tankas atrodè grèsmingai ${ }^{3}$. Vykęs sprendimas buvo daryti vikšrus ne per visą tanko aukští, kaip pirmuosiuose britų tankuose. Mažiau vykęs buvo tanko aukštis ${ }^{4}(3,3 \mathrm{~m}$, kai plotis buvo $3,1 \mathrm{~m})$, dèl ko svorio centras taip pat buvo aukščiau ir tankas lengviau galejo nuvirsti ${ }^{5}$. Kai tai suprasta, vèliau visos šalys ėmè gaminti labiau „prisiplojusius“ modelius, ko laikomasi iki šių dienų. Tiesa, Vokietijai po I pasaulinio karo buvo uždrausta gaminti tankus, tačiau jie buvo gaminami slaptai, bendradarbiaujant su Švedija, o išbandyti, bendradarbiaujant su Sovietų Sajunga. Tam buvo sukurta slapta tankų karo akademija: The Secret School of War: The Soviet-German Tank Academy at Kama ${ }^{6}$.

Sovietai kūrẻ savo tankus. Yra išlikusi įdomi nuotrauka iš parado Maskvoje XX a. 4-ojo dešimtmečio antroje pusèje - didžiulio tanko imitacija iš gyvu žmoniư ${ }^{7}$ (žiūrèti tinklalapio apačioje). Kažkas originalaus? Iš tikrujų, Sovietų Rusijoje pirmieji tankai pradèti gaminti, kopijuojant prancūziškuosius Renault. 1920 m. taip pagamintas pirmasis tankas, kuriam suteiktas pavadinimas „,Kovotojas už laisve draugas LENINAS“ (Борец за СВОБОДУ тов. ЛЕНИН ${ }^{8}$. Bent jau pavadinimas tikrai buvo originalus. 4-ajame dešimtmetyje sovietu tankai buvo gaminami, kopijuojant jau britų naujesnius tankus. Būtent toks buvo sovietų lengvasis tankas T-26 ir vidutinis tankas T-28. Jie naudoti ir okupuojant Lietuvą 1940 m. birželị.

Baltijos šalys tankus pirko. Didžiosios valstybės suprato, kad kariauti teks moderniais ginklais, o tankams čia turejjo tekti žymiai svarbesnis vaidmuo nei I pasaulinio karo metais. Tačiau tankus buvo galima pasigaminti, turint tik sunkiąją industriją, dèl to Baltijos valstybès dairèsi, kur čia jų nusipirkti. Tankų turejjo ir nepriklausomos Lietuvos kariuomenè - „Tankai Lietuvos kariuomenèje 1924-1940 m. ${ }^{\text {" }}{ }^{9}$ (2015 m. leidinys). Šiame leidinyje yra aprašomi bei parodomi Latvijos ir Estijos tankai. Baltijos valstybès pačios tankų negamino, o pirko iš kitų šalių.

Jubiliejiniai straipsniai. Pirmojo tankų panaudojimo proga praejjus šimtmečiui, $2016 \mathrm{~m}$. pasaulinėje žiniasklaidoje pasirodè nemažai straipsnių, apžvelgiančių tankų istoriją, primenant jų debiutą mūšsio lauke:

Tank at 100: Baptism of fire, fear and blood ${ }^{10}$ (BBC News, 2016-09-15)

100 Jahre Panzer: Von Mark I bis Leopard $2^{11}$ (Neue Zürcher Zeitung, 2016-09-15)

Stahlkolosse veränderten den Krieg: Vor 100 Jahren rollte der erste Panzer in die $\underline{\text { Schlacht }}^{12}$ (n-tv.de, 2016-09-15) Как танки изменились за 100 лет ${ }^{13}$ (Известия, 2016-09-15) ir kt. 
„Sausumos laivai“ nebijojo kulkų. I pasaulinio karo metais tankai perversmo karyboje nepadarè, tačiau jais buvo susidomèta neatsitiktinai, mat tame kare masiškai buvo naudojami kulkosvaidžiai, kurie labai sustiprino gynybos galimybes ir ženkliai stabdè pėstininkų puolimą. Šarvuoto judančio tanko idejja tokiomis sąlygomis atrode kariškiams ir konstruktoriams labai perspektyvi. Jei pirmasis tankų panaudojimas 1916 metais britams nebuvo itin sékmingas, tai 1917 m. ir 1918 m. atskiruose mūšiuose jau ėmè ryškèti, kokią galią turi siauresniame fronto ruože sutelktos tankų pajègos. I tai po karo atkreipẻ dèmesį ir susikūrusi lietuviška karinè žiniasklaida. Žr.: Iš tanku istorijos ${ }^{14}$ [Karys, 1922-06-14, Nr. 28, p. 329-332].

Paprasti ir giluminiai saitai buvo naudojami ir kuriant teksto dalị apie šiuolaikinius vokiečių tankus Leopard 2. Čia šiek tiek pasitelkta ir lengvo humoro. Nagrinejjant internetu prieinamą užsienyje naudotą mokomają medžiagą karine tematika, teko pastebėti, kad lengvo humoro dozè, kuri kaip intarpas pateikiama bendrame kontekste, nèra vengtinas dalykas, nes padeda geriau suprasti ir įsisavinti pagrindinę temą. Antai amerikiečiu 1944 m. mokomajame filme apie vokiečiu zenitinę patranką Flak buvo panaudotas intarpas iš Volto Disnejjaus (Walt Dysney) kompanijos animacinio filmo. Vaizduojamas epizodas, kaip medžiotojas šaudo ị skrendantị ančiuką, o tas, vargšelis, pašautas nusileidžia, išskleisdamas parašiutą. Tačiau iš karto po to žaismingo animacinio intarpo eina gana detalus balistinių dalykų paaiškinimas apie bene garsiausio II pasaulinio karo ginklo praktinị panaudojimą.

Toliau pateikiamoje teksto dalyje apie vokiečių tankus Leopard 2 tam tikra humoro dozè irgi randama. Taip yra dar ir dèl to, kad dabartiniuose pažinimui bei mokymui skirtuose filmukuose šypseną sukeliančios situacijos taip pat fragmentiškai naudojamos. Antai ị YouTube kanalą ịkeltame vokiečių filmuke tankas Leopard 2 pravažiuoja neišlaistydamas alaus bokalo, o po šių kadrų iš karto rodomos dinamiškos schemos su paaiškinimais apie tanko stabilizavimo sistemos konstrukciją.

\section{Vokiečių tankas Leopard ${ }^{2}$}

Šiuolaikinio vokiečių tanko Leopard 2 stabdymo galimybès. Rodomas pavykęs variantas. Vienas kariūnas komentavo taip: „Kiek reikèjo ištaškyti, kol pavyko?“ Humoras, žinoma...

\section{YOUTUBE $2014 \mathrm{~m}$. vaizdo ịrašas ${ }^{15}$}

Juokas juokais, bet Leopard 2 laikomas vienu geriausių tankų pasaulyje, o sako, kad ir buvo pats geriausias. Bent tokiu $2002 \mathrm{~m}$. ji pripažino kariniai ekspertai: Geriausi lèktuvai - amerikietiški, o tankai - vokiški ${ }^{16}$. Šių tankų yra ir Baltijos šalyse. $2014 \mathrm{~m}$. Latvija juos pirko iš Nyderlandų. Tais metais ị NATO pratybas Lietuvoje buvo atvažiavę 4 naujesnès modifikacijos tankai Leopard 2 A5. O 2017 m. su tankais Leopard 2 i Lietuvą atvažiavo vokiečiai, kurie veiks NATO bataliono sudètyje. Sprendimas priimtas 2016 m. rudenị: Patvirtinta: Vokietija Lietuvoje dislokuos tankus ${ }^{17}$. Šio tanko igulą sudaro 4 žmonès: vizualizacija 7:03-7:12 ${ }^{18}$. Tankas gerai šaudo, nes turi gerą stabilizavimo sistemą: važiuojant alaus bokalo neišlaisto ${ }^{19}$. 
Moteris tankistė? Vyrai, laikykitės, 2017 m. gegužès mėnesị pastiprinimui ị Lietuvą atvyksta leitenantė Silje Johansen Willassen, pirmoji moteris Norvegijoje, vadovaujanti 4 „Leopard“ tankų būriui (žr. 1 pav.).

\section{„YOUTUBE“ VAIZDO ĮRAŠAS}

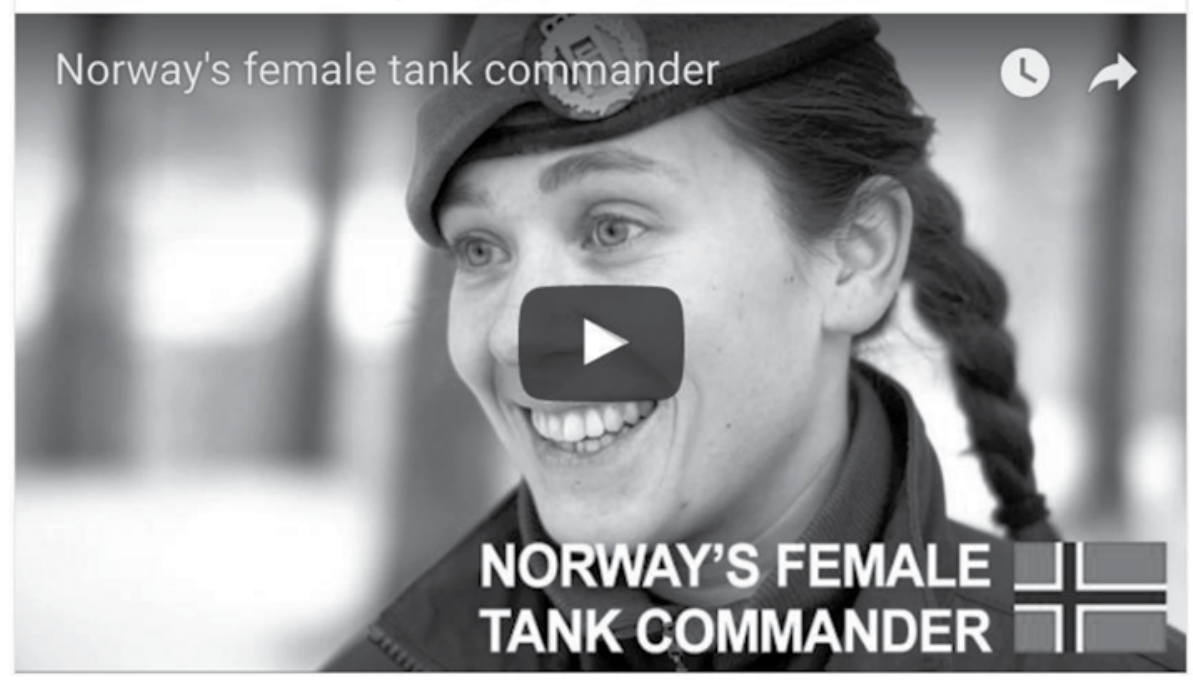

\section{1 pav. YOUTUBE $2017 \mathrm{~m}$. vaizdo irašas ${ }^{20}$}

Leo šarvai - geriausi priekyje. Leo - taip meiliai vokiečiai sutrumpintai vadina savo tanką Leopard. Vis dèlto Leopard 2 pasirode pažeidžiamas iš šono ir galo, mat kaip ir visi tankai konstruoti frontalinei atakai, dèl ko stipriausi šarvai priekyje, o iš šonų ir gale - silpnesni, taip neperviršijant svorio ir išlaikant mobilumą. Tanko Leopard konceptas pradètas kurti dar 1963-iaisiais, t. y. „Šaltojo karo“ metais, ịsivaizduojant, kad sovietai puls Vakarus su tankais per Fuldos koridorių Vokietijoje, kur jų sulaikymui kaip tik ir galèjo išvažiuoti naujieji tankai, itin apsišarvavę iš priekio. NATO strategai prie Fuldos planavo generalinį tankų mūši, turejjusị sulaikyti tolesnę sovietų invaziją, kol būtų pritrauktos papildomos Vakarų šalių karinès pajègos. Sėkmingai pratestavus, pirmieji Leopard 2 tankai Bundesverui oficialiai tiekti nuo $1979 \mathrm{~m}$.

Sirijoje sugriautas „Leopardų“ mitas. Islamo valstybės teroristams pavyko su rusų gamybos raketomis $2016 \mathrm{~m}$. gruodžio mènesį prie Sirijos miesto al-Babo sunaikinti keletą „Leopardų“, naudojamų Turkijos karinėse pajègose. Teroristai skelbia, kad sunaikino net 10 „Leopardụ“. Oficialiai turkai to nepatvirtino, tačiau kariniai ekspertai, išnagrinèję teroristų paskelbtą video medžiagą, neabejoja bent dèl dalies to skaičiaus. Apie tai $2017 \mathrm{~m}$. sausị rašè įtakingas Vokietijos dienraštis „,Die Welt“621, komentavo ir kiti žiniasklaidos ruporai. Tiesa, kalba eina apie senesnị Leopard 2 A4 modelį. Jis dabar Bundesvere jau nenaudojamas.

Turkijos vokiški tankai pašauti miesto prieigose. Leopard 2 A4 modelis, gamintas 1985-1992 m., yra labiausiai paplitusi versija. Sprendžiant iš vokiečių spaudos pranešimų, prie al Babo buvo pašauti būtent tie tankai, kurie pasiekè miesto ribą, o teroristai galèjo prie jų priarteti iš šono ir užpakalio, taip išnaudodami silpnają „Leopardų“"vietą. Vokiečių ekspertai, išnagrinèję video medžiagą, laiko, kad prie tankų nuostolio galejo prisidèti ir blogas vadovavimas. Mat susidaro ịspūdis, kad Turkijos tankai veikè pavieniui. Jie turètų veikti bendromis pajègomis, palaikomi artilerijos, o iš šonų dengiami pèstininkų. Apie tai rašè „,Frankfurter Allgemeine Zeitung “22. 
Naujausi Leopard 2 variantai. Kardinalus apsaugos sprendimas būtų techninio pobūdžio, įdiegiant aktyvios gynybos sistemą, tačiau ji yra tik kūrimo stadijoje. Net ir naujausias Leopard 2 variantas, žymimas indeksu A7, ir dar naujesnis A7+ kol kas jos neturi. Kuriamas naujas Leopard 2 variantas A7V dar nepasirodè - ji bandymams numatoma duoti Bundesverui 2018 m. III ketvirtyje. I naujo modelio numeracijos indeksą įrašant raidę $V$, pažymimas žodis verbessert, kas išvertus reiškia ,pagerintas“. Tokiu modelio pavadinimu vokiečiai nori pažymèti ir savo pirmojo funkcionalaus tanko šimtmetị. Taigi, $2018 \mathrm{~m}$. išriaumos tankai, indeksuoti A7V, t. y. kaip ir tie, kurie pasirode 1918-aisiais. Leopard 2 A7V atspindès tai, ką vokiečiams pavyko pasiekti tankų gamybos srityje per 100 metų.

Šiais tekstais vikyje „Karybos istorija“ galima manipuliuoti, juos adaptuoti individualiems ar grupiniams poreikiams, supaprastinti arba kaip tik išplètoti, atnaujinti, aktualizuoti, papildyti klausimais, užduotimis ir t. t. $2017 \mathrm{~m}$. gegužès mènesị i Lietuvą su tankų būriu atvykus leitenantei Siljei Johansen Vilasen (Silje Johansen Willassen), apie ją ir tankus Leopard 2017 m. birželio 1 d. pasirodè straipsnis naujienų portale Delfi.lt. Dėl to vikio tekste ịterpiau saitą į korespondento Vaido Saldžiūno parengtą straipsnį (Saldžiūnas, V., 2017), taip atnaujindamas informaciją. Jei nepatinka teksto struktūra, gali ji perstruktūruoti ir pan. Toks tekstų redagavimas bei keitimas galètų tapti studijavimo proceso dalimi. Čia pateikiama tik dalis vikio, o visas tinklalapis apie tankų šimtametę istoriją gali būti traktuojamas kaip karybos istorijos mokomosios priemonès atskiras skyrius. Tai nèra enciklopedinis turinys, bet mokymuisi skirti skaitiniai, metodinès priemonès, vadovèliniai tekstai ir neturi būti rašomi kaip enciklopedijai.

1.3. Keli praktiniai patarimai. Viena iš praktinių problemų, naudojant saitus - tai jų funkcionavimas. Jie nèra amžini: keičiasi resurso talpinimas serveriuose, internetiniai adresai, resursas panaikinamas, apribojama prieiga atskiroms šalims ir t. t. Tačiau saitų aktualizavimas dažnai nėra tokia jau sudėtinga problema, mat resursui išnykus vienoje vietoje, jis neretai atsiranda kitur, o saitus nesunku atnaujinti. $\mathrm{Be}$ to, naratyvinèse hiperteksto struktūrose vieną objektą internete galima pakeisti kitu panašaus pobūdžio, ịterpiant naują saitą.

Norètųsi atkreipti dėmesị ir ị kai kuriuos techninius dalykus. YouTube kanale giluminis saitas sukuriamas, pridedant prie internetinio adreso galūnę pagal schemą \#t=XmYs, kur X reiškia minutės skaičių, o Y - sekundès skaičių. PDF faile nuoroda ị konkretų puslapi gaunama prie dokumento internetinio adreso, besibaigiančio galūne pdf, pridedant puslapio numerị \#page $=\mathrm{n}$, kur $\mathrm{n}$ reiškia dokumento puslapio numerị. Dèti saitus ị grafinius failus (jpg, png, gif) taip pat nesunku - tereikia kopijuoti ne svetainès, kurioje yra vaizdas, o pačio grafinio failo internetini adresą ir ji panaudoti hipersaito sukūrimui. Ši funkcija yra svarbi ir dèl autorinių teisių, mat radęs internete tinkančią nuotrauką ar paveiksliuką, nukopijavęs grafinius failus, ne visada gali juos laisvai panaudoti savo teksto iliustracijai. Būtina atsiklausti jų autorinių teisių savininkų, gauti leidimą kopijuoti, pasinaudoti ir publikuoti, platinti. 
Dèl to gali atsirasti papildomų problemų. Pakeitus giluminị saitą viešai prieinamu failu, daugelio šių problemų išvengiama.

Dèl saitų naudojimo vis dèlto teisinejje praktikoje yra buvę kolizijų, tačiau giluminio saito panaudojimas dažniausiai nebuvo laikomas intelektinès nuosavybès pažeidimu. Vokietijos federalinis teismas (vok. Bundesgerichtshof) $2003 \mathrm{~m}$. konstatavo, kad jei turinio pateikejas atskirus dokumentus daro laisvai prieinamus internete ir be apribojimų, tai tada yra legitimu ir leistina déti nuorodas, naudojant giluminius saitus (Stadler, T., 2003).

Dar viena pastaba dèl teksto pateikimo. Yra žinoma, kad tekstas, užimantis visą ekraną ir nepadalintas ị atskiras mažesnes dalis, nėra patogus skaityti. Dél to tekstas vikiuose irgi, paprastai, struktūruojamas, suskirstomas ị nedidelius teksto paragrafus. Turint išmaniuosius telefonus, planšetes ir t. t., toks požiūris dar labiau pasiteisina. Vikipediją valdantis operatorius The Wikimedia Foundation planuoja dar labiau optimizuoti laisvają enciklopediją ir kitus projektus, atsižvelgiant ị išmaniuosius įrenginius su mažu ekranu (Dredge, S., 2016). Be to, kuriamos programèlès specialiai mobiliesiems ịrenginiams, palengvinančios giluminius saitus (angl. mobile deep linking). Situacija su saitais, jų funkcionavimu dabar yra geresnè nei prieš keliolika metų. Tai gera žinia istorikams ir studijų dalyviams, nes galima skirti daugiau demesio istoriniam turiniui, jo analizavimui, kūrybiniam pritaikymui ir perteikimui, naujų naratyvinių konstrukcijų kūrimui, o ne techninès natūros problemoms.

Taip pat atkreiptinas dèmesys į tai, kad istorijos temomis nemažai publikuojančiais pripažinti plačiajai visuomenei skirti iliustruoti žurnalai, tiksliau, jų autoriai, daugeliu atvejų nesilaiko gana mažais tiražais leidžiamų akademinių žurnalų ir kai kurių aukštụjų mokyklų metodiniuose rašto darbuose išdèstomų reikalavimų rašyti pagal vieną ir tą pačią schemą. Realiame gyvenime yra pasirenkamos ịvairios kūrybinio rašymo strategijos, tik dalinai susijusios su akademinio mokslo reikalavimais, kas leidžia sudominti didesnius skaitytojų sluoksnius, kurie mokslinių straipsnių neskaito apskritai (Vyšniauskas, A., 2012).

İ mokslo populiarinimui naudingą stilistiką reikètų atsižvelgti ateityje, suteikiant galimybes ir kariūnams rengti tokius rašto darbus, kuriuos nesunku būtų adaptuoti straipsnio publikacijai ,glianciniame“ žurnale, karinio dalinio informaciniame leidinyje, naujienų internetiniame portale ir t. t. Reikia nepamiršti, kad mokslininkų rengimas yra numatytas trečiojoje universitetinių studijų pakopoje, doktorantūroje, kurioje studijuoja tik nedidelis procentas turinčiųjų magistro diplomą. Studijuojant bakalauro lygmenyje, be akademinio rašymo pradų suteikimo, svarbus galètų būti ir įvairesnès naratyvinès patirties ịgijimas, įskaitant kūrybišką eklektiką. 


\section{Globalinès vadovèlinès perspektyvos}

Vienas iš projektinio darbo formų trūkumų yra tai, kad studentai, ịsigilinę i vieną ar kitą siauresnę probleminę temą, nors ir gali sukurti dèmesio vertą kūrybini rezultatą, tačiau automatiškai negauna sisteminių žinių apie studijuojamo dalyko visumą. Panašiai galima kalbėti apie studentų rašto darbus, rašomus viena ar kita daugiau ar mažiau siauresne tematika. Visuminio požiūrio formavimui studijų eigoje turètų pasitarnauti vadovèlis, kuriame mokymo(si) tikslais sistemiškai išdèstoma medžiaga. Tačiau ar šiais laikais vadovèlis turi būti toks, koks buvo anksčiau? Toliau bus apžvelgta keletas ieškojimų krypčių, bandančių sukurti kažką naujo ir originalaus šioje srityje.

\subsection{Skaitmeninė mokymosi platforma turi būti ekonomiškai efektyvi.}

Beveik neabejojama, kad naujos technologinès galimybès keičia studijas ir mokymosi procesą ir toliau ji keis, tačiau, kaip ir ką daryti mokymo pajègoms naujomis sąlygomis konkrečiai, tai dar nèra pakankamai išsikristalizavę dalykai, nors bandymų modernizuoti mokymosi procesus yra nemažai. Stambiausia pasaulyje leidybinè ir edukacinè korporacija Pearson jau keletą metų skelbiasi kurianti debesų kompiuterija pagrįstą globalinę skaitmeninę mokymosi platformą, kuri revoliucionizuos visą edukacinę industriją, leis pasiekti rinkas, kurių iki šiol ši korporacija neaptarnavo. Manoma, kad tai pavyktų bendradarbiaujant su edukatoriais ir švietimo institucijomis, kartu ieškant asociacijų su tokiais skaitmeninių medijų gigantais kaip Facebook, Amazon ar Netflix (Ismail, N., 2016).

Pearson yra komercinè korporacija. Dèl to, net ir radus efektyvius skaitmeninès platformos modelius edukacine prasme, neaišku, ar jie pasiteisins ekonomiškai. Microsoft nuo 1993 m. leidžiama elektroninè multimedija - enciklopedija Microsoft Encarta - savo laiku buvo nebloga, tačiau tolesnis jos leidimas tiek diskuose, tiek online 2009 m. buvo sustabdytas. Microsoft Encarta XX a. paskutiniajame dešimtmetyje revoliucionizavo enciklopedini medžiagos pateikimą. Pasinaudodama jau kitų sukurtais enciklopediniais tekstais, ji skyrè ypač didelị dèmesi informacijos pateikimo vizualiniam patrauklumui, pridedant daug grafikos, filmuotos medžiagos, audio failų. Prieš tradicines spausdintas enciklopedijas buvo laimima ir vykdant agresyvią kainų politiką. Už beveik 100 dolerių buvo galima ịsigyti didelès enciklopedinès informacijos talpos keletą CD-ROM disku ar vieną DVD, sutaupant šimtus ir tūkstančius dolerių, palyginus su daugiatome spausdinta enciklopedija. Neretai enciklopedijos Encarta kaina buvo įskaičiuojama ị naujo kompiuterio bendrą kainą, įsigijant naują kompiuterị su Microsoft Windows operacine sistema. Tačiau pasikeite sąlygos, atsirado Web 2.0, kurio vienu iš labiausiai žinomų dalykų tapo laisvoji enciklopedija Vikipedija, kuriama ir platinama nemokamai. Microsoft neatlaikè konkurencijos (Kleinz, T., 2009). Jai tiesiog neapsimokejo toliau investuoti ị enciklopedinị projektą, negaunant ịdètų lèšų susigrąžinimo ir pelno. 
Reikšminga, kad kompiuterių klasès, lingafoniniai kabinetai, kalbos laboratorijos, kuriomis taip didžiavosi kai kurie švietimo ịstaigų vadovai, šiais laikais taip pat jau laikomi seniena. Žymiai svarbiau yra turèti gerą interneto ryšĭ nes beveik kiekvienas besimokantysis turi mobilų išmanujjị ịrenginị ir/ar kompiuterị. Vokietijoje pastaruoju metu bus skiriamas padidintas dèmesys mokykloms, kuriant kokybiškus bevielius tinklus. İ pagalbą siūlosi ir Google korporacija, jau stipriai ịkèlusi koją $\mathfrak{i}$ Indijos ir kai kurių kitų šalių švietimo sistemas ne tik infrastruktūros kūrimo prasme, bet ir turinio teikimo galimybėmis. Vokiečiai akcentuoja, kad šalis atsilieka skaitmeninès švietimo aplinkos srityje, o internetinio ryšio kokybès ir e-paslaugu prasme sektinais pavyzdžiais neretai nurodomos žymiai mažesnès šalys, tarp jų ir Estija. Pasinaudojant debesų kompiuterijos galimybemis, sudaryti palankią skaitmeninę aplinką mokytis ne tik informatikos, bet ir vokiečių kalbos ar istorijos taip aktualiai keliamas tikslas Vokietijoje (Kloepfer, I., 2017). Savaime suprantama, kad saitų ir konkrečiai giluminių saitų kūrimas pasauliniame žiniatinklyje dèl tokių permainų tik didès ir jo reikšmė kils. Turint omenyje vieną sparčiausių pasauliniu mastu internetinio ryšio greitị Lietuvoje, šia technine sąlyga mums reikètų tinkamai pasinaudoti, pas save kuriant ir platinant vertingą dalykinị turini, pritaikant ji savišvietai ir kolektyviniam mokymuisi.

2.2. Postskaitmeninio vadovèlio idèja. Jei popierinio tipo vadovèlị paversi skaitmeniniu tekstu ir be statiškų iliustracijų pridèsi dar ir kitos įdomios grafinès medžiagos, video, animacijų su garsiniais efektais, žaidybinių elementų ir t. t., tai gausis skaitmeninis vadovèlis. Tokio tipo vadovèlius leidžia ir Lietuvos leidyklos. Pirmasis Lietuvoje istorijos vadovèlis skaitmeniniu formatu buvo išleistas $2002 \mathrm{~m}$. Jo sudarytojas, redaktorius ir projekto vadovas - Eugenijus Jovaiša, o dirbo gausi istorikų ir kitų specialistų komanda (Gimtoji istorija, 2002). Buvo ir antrasis vadovèlio leidimas, o jo medžiaga dabar yra prieinama ir internete. Sukūrimo metu tai buvo itin modernus dalykas, turintis išliekamają vertę, tačiau skaitmeninis vadovèlis „Gimtoji istorija“ pagamintas dar iki Web 2.0 atsiradimo.

Dabar pasaulyje jau yra keliama postskaitmeninio vadovèlio (angl. post-digital textbook) ideja. Post-digital sąvoka, gimusi kūrybinio meno teoretiku aplinkoje (Cascone, K., 2000), šiuo metu vis plačiau imama vartoti platesnèmis prasmėmis. Terminas, angliškai rašomas post-digital, postdigital, post digital, tęsia savo pritaikymo karjerą. Antai atsirado postskaitmeninio pasaulio sąvoka, kuria apibūdinama padètis, kai skaitmena - digitalis - yra integruota ị mūsų kasdienị gyvenimą (Doty, C., 2016). Kūrybą, švietimą ir daugelị kitų dalykų galiausiai lemia ne technologijos, o kultūra, ne robotai, o žmonès. Bet tie žmonès naudoja technologinius prietaisus natūraliai savo aplinkoje.

Tokios permainos, kai trinasi ribos tarp skaitmenizuoto pasaulio ir kasdienio gyvenimo, inspiravo idèją, ị kurią norisi atkreipti dèmesị švietimo ir studijų tolesnès perspektyvos srityje. Tai JAV valstybiniame Arizonos universitete $2014 \mathrm{~m}$. pradètas ambicingas postskaitmeninio vadovèlio projektas, vykdomas 3 mokslinin- 
kų. Jis fokusuotas i naują mokymosi technologiją, kurioje personalizuotas mokymasis būtų kombinuojamas su bendradarbiavimu, resursų dalinimusi, mokymąsi suprantant kaip socialini procesą. Projekto vykdytojai žiniasklaidoje konstatavo, kad ikišioliniai skaitmeniniai vadovèliai yra nuobodūs. Projekto tikslas būtų sukurti postskaitmeninio vadovèlio prototipą, kuris būtų toks reikšmingas, kad galètų pakeisti vyraujanti mokymąsi iš tradicinio materialaus vadovèlio - popierinio ar skaitmeninio. Vadovèlis turi tarnauti ne tik kaip žinių sistema, bet ir kaip bendradarbiavimo išteklius.

Postskaitmeninis vadovèlis turètų būti kažkas nauja, kas galètų efektyviai funkcionuoti socialiniuose tinkluose, kolektyviai mokantis, derinant individualias mokymosi trajektorijas su komunikacija kolektyve. Tam naujam mokymosi technologijos žanrui gal ir ne visai tiks vadovèlio terminas, bet šiuo atveju norima pasakyti, kad tas naujas mokymasis bus toks pats svarbus, kaip anksčiau buvo iš vadovèlio. Dotacija iš pradžių gauta 2 metams, skyrus 299 tūkst. dolerių finansavimą. Projektas startavo $2014 \mathrm{~m}$. rudenį, bet $2015 \mathrm{~m}$. vasarą buvo pakoreguotas, o visas biudžetas padidintas iki 315 tūkst. dolerių. Vèliau JAV Nacionalinio mokslo fondo interneto svetainèje preliminariai buvo nurodyta projekto užbaigimo data $-2017 \mathrm{~m}$. liepos 31 d. (EAGER. 2014-2017). Internete apie projekto eigą nebuvo skelbiama. Neaišku, ar projektas bus sėkmingai užbaigtas, ar geidžiamas postskaitmeninio vadovèlio prototipas bus iš tikrųjų sukurtas.

Kaip ten bebūtų, išeities pozicija yra reali, mat iš savo gyvenimiškos praktikos ir mokymosi aplinkos stebejjimo galiu konstatuoti, kad šiuolaikiniam jaunimui nepatinka „kalimas iš vadovèlio“, nes jau kelerių metų vaikas auga, baksnodamas planšetinị kompiuterị ar kitą išmanųjų ịrenginị. Neretai svarbūs ar ne taip svarbūs dalykai sužinomi, bendraujant su draugais Facebook ar kituose socialiniuose tinkluose, tačiau tokiais atvejais kyla klausimas, ar sisteminių žinių formavimui ir jų individualiam ịsisavinimui yra reikalingas standartinis vadovèlis kaip masių instruktavimo ginklas?

\subsection{Ar apskritai šiais laikais vadovèlis reikalingas universitetinėse stu-} dijose? Keliant tokị klausimą, noretųsi pateikti fragmentą iš asmeninio pokalbio su jaunu fotografu. İ mano klausimą, koks turètų būti geras fotografijos vadovèlis, jis atsakè: „Visu pirma [trumpa pauzè], nereikia skaityti jokio vadovèlio!“ Stebèdamas tą jaunaji fotografą, aš matau, kaip jis tobulejja, tačiau popierinis vadovèlis ar skaitmenintas jo atitikmuo kompiuterio ekrane jam iš tikrujjų kaip ir nereikalingas. Kadangi, gilinantis $\mathfrak{i}$ fotografavimo paslaptis, „lendama“ $\mathfrak{i}$ internetą, ten randami įvairūs patarimai, mokomieji filmukai (angl. tutorials), sekama žymiausių pasaulio foto meistrų kūryba, skaitomi nuotraukų komentarai ir t. t. Sava kūryba, irgi talpinama į Instagram ar kitas žiniatinklio buveines, susilaukia kritikos ar pagyrimų, patarimų, aptariama socialiniuose tinkluose ir pan. Spausdinta produkcija kažkiek irgi žiūrima, bet tai - ne vadovèliai, o fotoalbumai, iliustruoti žurnalai, reklaminiai leidiniai su nuotraukomis ir pan. Tad, ar negali būti universalaus vadovèlinio mo- 
delio, kaip efektyviai išnaudoti šiuolaikines pasaulinio žiniatinklio galimybes mokymosi ir studijų tikslais? Tuo labiau, kad beveik kiekvienas jaunuolis šiais laikais turi išmanujį telefoną su interneto prieiga.

Vadovèlis aukštosiose mokyklose kaip sisteminis žinių pateikimas mokymo tikslais, mano supratimu, vis delto yra reikalingas. Tačiau, jei kalba eina apie labai kompleksiškas žinių sritis, kyla klausimas, ar būtina jị nuosekliai skaityti? Jei žiūrètume istorines žinias, tai istorijos vadovèlių tikslas yra parodyti didelius istorijos tarpsnius apibendrintai sutraukta forma. Nors pasaulio istorijos vadovèliai universitetų studentams atskirose šalyse būna leidžiami, tačiau kai kurie istorijos studijų specialistai reiškia mintį, kad tokio vadovèlio nuoseklus skaitymas vis dèlto yra mažai perspektyvus dalykas. Atmintis nèra pajègi ịsisavinti labai koncentruotos medžiagos kiekius su daugybe faktų, dèl to ir vadovèlį siūloma naudoti tik kaip parankinę priemonę. Tarkim, nagrinėjant kokią nors specialią temą, ją traktuoti kaip stambesnès temos apibrèžto laikotarpio dalị ir tada pasižiūrèti, kaip to laikotarpio sąryšiai atskleidžiami vadovėlyje (Opgenoorth, E., Schulz, G., 2001: 273). Būčiau linkęs pritarti tokiai nuomonei.

\section{İžvalgos ir apibendrinimai}

1. Studentų interaktyvumo didinimas yra pažymimas kaip viena iš prioritetinių studijų modernizavimo krypčių. Rišlaus hiperteksto kūrimas, dalinimasis, tobulinimas, adaptavimas ir t. t. yra vienas iš perspektyvių studijų metodikos atnaujinimo dalykų. Norètųsi atkreipti dèmesị i giluminius saitus kaip itin svarbų komponentą, kuris bus pravartus, pereinant prie naujų mokymosi kelių, pagrịstų bendravimu socialiniuose tinkluose ir mokymosi platformose. Karybos istorijos studijos, integruojančios daugelio dalykų žinias, yra tinkama terpè savo potencialu, apibrèžtumu ir tikslingumu naudotis interneto resursais, juos kūrybiškai sujungiant paprastaisiais ir giluminiais saitais, tam naudojant vikius bei kitas debesų kompiuterijos galimybes.

2. Kuriant studijoms vertingą medžiagą, ypatingą reikšmę igyja ne tik sukauptos žinios, euristiniai gebėjimai, vizualinè vaizduote, bet ir literatūrinis kūrybiškumas, mat, orientuojantis ị populiarèjantị integruotą mokymą(si), daugeliu atveju nẻra lengva susieti skirtingų dalykų medžiagą, įvairių šalių ir skirtingų pasaulio geografinių regionų procesus, ịvykius, faktus tiesioginiais priežastiniais ryšiais. Daugeliu atvejų vis dẻlto, bent tam tikruose medžiagos apdorojimo etapuose, teksto rišlumą pasiekti padeda ịvairios literatūrinès technikos, o neretai ir literatūrinès improvizacijos. Dirbant su literatūriškai rišliais bei suprantamais tekstais, tolesniuose etapuose gali būti siekiama ir konceptualaus gilumo.

3. Turint omenyje mokslinès prozos reikšmę ir vieną iš kriterijų kurti mokomają medžiagą patrauklia literatūrine forma, reikètų atkreipti dèmesị ị kariūnų rašto darbų reikalavimų tobulinimą, labiau atsižvelgiant ị humanitarinių mokslų dvasią ir tai, kad naratyviniai gebèjimai yra reikalingi kariškio profesiniame gyve- 
nime. Tam būtina numatyti didesnę rašto darbų formų ir stilių įvairovę. Istorija yra viena iš humanitarinių disciplinų, o šio dalyko studijavimas turètų padèti kariūnams kurti istorinius pasakojimus, kurie nebūtinai reikštų griežtai apibrěžtų tyrimo metodų taikymą pagal iš anksto nustatytą schemą. Galbūt tokie rašytiniai pasakojimai ar kūrybiški hipertekstai netiks kanonizuotai akademinei spaudai su savo griežtos struktūros ir kitokiais reikalavimais, tačiau jie gali būti naudingi mokymosi procesams istorijos perteikimo prasme ir visuomenès švietimui. Romanai rašomi ne pagal taisykles, o straipsniai ị „Iliustruotasis mokslas“ bei kitus mokslo populiarinimo žurnalus parengiami dažniausiai irgi pagal savus skaitytojų dėmesị patraukiančius kriterijus, kurie su akademiniais sutampa tik dalinai. Mokslinè proza apie praeitị, jos susiejimas su dabartimi gali būti kūriama, išreiškiant savo jausmus ir nuomonę, nevengiant humoro, gyvos kalbos ir daugelio kitų dalykų, kuriais pasižymi kūrybiškas humanitarų cechas.

\section{Šaltiniai ir literatūra}

1. Cascone, K. (2000). The Aesthetics of Failure: "Post-Digital" Tendencies in Contemporary Computer Music. Computer Music Journal. Vol. 24, No. 4 (Winter, 2000), pp. 12-18.

2. Dagienè, V., Grigas, G., Jevsikova, T. (2008). Enciklopedinis kompiuterijos žodynas. Vilnius.

3. Doty, C. (2016). Have What It Takes To Win In A Post-Digital World? Carlton Doty's Blog. May 4, 2016. Prieiga per internetą: $<$ http://blogs.forrester.com/ carlton_doty/16-05-04-have_what_it_takes_to_win_in_a_post_digital_world >

4. Dredge, S. (2016). Wikipedia launching $\$ 100 \mathrm{~m}$ fund to secure long-term future as site turns 15 . Theguardian.com. 15 January 2016. Prieiga per internetą: $<$ https://www.theguardian.com/technology/2016/jan/15/wikipedia-fund-future $>$

5. EAGER. (2014-2017). EAGER: Towards Knowledge Curation and Community Building within a Postdigital Textbook. Award Abstract \#1451431. National Science Foundation. Prieiga per internetą: $<$ https://www.nsf.gov/awardsearch/ showAward?AWD_ID $=1451431>$

6. Flak. (1944). Flak. Official Training Film / First Motion Picture Unit, [US] Army Air Forces. T. F. I-3389. Prieiga per internetą: <https://www.youtube.

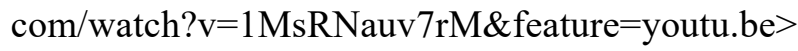

7. Gimtoji istorija (2002). CD - Gimtoji istorija. Nuo 7 iki 12 klasès / sudarytojas, redaktorius ir projekto vadovas Eugenijus Jovaiša. Vilnius: Elektroninės leidybos namai.

8. Ismail, N. (2016). Pearson is in the process of creating a global digital learning platform that it believes will revolutionise the education industry. Information Age. 17 October 2016. Prieiga per internetą: <http://www.information-age. com/pearsons-learning-platform-123462720/>

9. Kleinz, T. (2009). Encarta: Microsoft stellt Online-Lexikon ein. Focus 
online. 2009-03-31. Prieiga per internetą: $<\mathrm{http} / / / \mathrm{www}$.focus.de/digital/internet/encarta-microsoft-stellt-online-lexikon-ein_aid_385746.html>

10. Kloepfer, I. (2017). Digitalisierung: Google erobert die Schulen. Faz.net. 17-04-2017. Prieiga per internetą: <http://www.faz.net/-gqe-8wxjr>

11. Lässig, S., Pohl, K. H. (Hrsg.) (2007). Historisches Forschen und Entdecken in Schule und Hochschule. Schwalbach/Ts.: Wochenschau Verlag.

12. Military Wiki [interaktyvus]. Prieiga per internetą: $<$ http://military.wikia. com/wiki/Main_Page>

13. Morkytė, E. (2007). Saitai intelektinès nuosavybès teisès požiūriu (autorių teisių aspektai). Teisè. T. 64, p. 76-91.

14. Opgenoorth, E., Schulz, G. (2001). Einführung in das Studium der neueren Geschichte. 6., grundlegend überarbeitete Auflage. Durchgesehene Neuausgabe. Paderborn, München, Wien, Zürich: Ferdinand Schöningh, S. 273.

15. Saldžiūnas, V. (2017). Norvegijos tankų būrio vadè žino, ką darytų Lietuvoje išvydusi rusų tankų koloną. Delfi.lt, 2017-06-01. Prieiga per internetą:

$<$ http://www.delfi.lt/news/daily/medijos-karas-propaganda/norvegijos-tanku-burio-vade-zino-ka-darytu-lietuvoje-isvydusi-rusu-tankukolona.d?id $=74809802>$

16. Stadler, T. (2003). Die Zulässigkeit sog. Deep-Links - Eine Anmerkung zur Paperboy-Entscheidung des BGH $=$ JurPC Web-Dok. 274/2003. JurPC (Internet-Zeitschrift für Rechtsinformatik und Informationsrecht). JurPC Web-Dok. 283/2003 - DOI 10.7328/jurpcb/20031811291. Prieiga per internetą: $<$ http://www. jurpc.de/jurpc/show?id=20030283>

17. Vyšniauskas, A. (2002). Istorijos studijų modernizavimas informacijos amžiuje. Naujoji paradigma praktikams / Mokymo metodikos knyga. Vilnius: Vilniaus universiteto leidykla.

18. Vyšniauskas, A. (2012). Tiesos sakymo būdai: grynasis ir su priemaišomis. Kultūros barai. Nr. 5, p. 82-87.

19. Vyšniauskas, A. (2015). Głębokie linkowanie w Internecie jako podstawa kreatywnej działalności dla historyka. Multimedia a źródła historyczne w nauczaniu i badaniach / Redakcja Mariusz Ausz; Małgorzata Szabaciuk. Lublin: Wydawnictwo Uniwersytetu Marii Curie-Skłodowskiej, s. 295-306.

20. Вендлянд, А. В. (2012). Анна Вероніка Вендлянд : «Добрі історики $\epsilon$ креативними еклектиками». Historians.in.ua. 26 March 2012. Prieiga per internetą: <http://www.historians.in.ua/index.php/en/intervyu/194-anna-veronika-vendliand-dobri-istoryky-ie-kreatyvnymy-eklektykamy> 


\title{
THE USE OF DEEP LINKS IN CREATIVE ACTIVITIES OF HISTORICAL STUDIES
}

\author{
Assoc. Prof. Dr. Arūnas Vyšniauskas \\ The General Jonas Žemaitis Military Academy of Lithuania
}

\section{Summary}

The World Wide Web has changed during the past 15 years. In the new conditions of Web 2.0 and post-digital environment, we require the very new training and learning solutions: communication on the basis of social networks, new digital learning platforms, implementation of ideas for post-digital textbook, creative eclecticism, cloud collaboration, creating networked knowledge, generating combinatorial creativity, etc.

The article raises the importance of deep links for increasing interactivity in history studies giving the examples of hypertext, which combines external hyperlinks and deep links examining the history of military tanks, linking it with current military realities. Academic study of military history integrates the knowledge of many things. It is a relevant field of study to use the Internet resources and to combine and make hyperlinks in a creative way. The author gives practical advice by making deep links and the use of web pages with wiki functionality. In conclusion, it is recommended to expand the variety of writing styles with different types of texts for students, i.e. cadets. It is important for self-regulated learning and skills development for creating scientific texts and content in the spirit of digital humanities and preparing various publications not only for academic purposes.

In the last part of the article, the author discusses the relationship among learning-by-doing, project method and traditional concept of textbook as a system of knowledge for learning purposes. A traditional and military world history textbook remains significant, but for higher education it must be reoriented on demand and related to ad-hoc functionality similar to the use of encyclopedic texts. 


\section{AUTORIAUS LYDRAŠTIS}

Autoriaus vardas, pavardė: Arūnas Vyšniauskas

Mokslo laipsnis ir vardas: humanitarinių mokslų daktaras

Darbo vieta ir pareigos: Generolo Jono Žemaičio Lietuvos karo akademijos Humanitarinių mokslų katedros docentas

Autoriaus mokslinių interesų sritys: Lietuvos istorija; globalinè ir transnacionalinè istorija; karybos istorija; geopolitika; lyginamieji vadovèlių tyrimai

Telefonas ir el. pašto adresas: + 37067535 227; vysniauskas@gmail.com

\section{AUTHOR'S COVER LETTER}

Author's name and surname: Arūnas Vyšniauskas

Academic degree and name: Doctor of Humanities (History)

Workplace and position: The General Jonas Žemaitis Military Academy of Lithuania, Department of Humanities

Author's research interests: history of Lithuania, global and transnational history, military history, geopolitics, international textbook research

Telephone and e-mail address: +370 67535 227; vysniauskas@gmail.com 
1 http://www.bbc.co.uk/history/interactive/animations/mark_one_tank/index_embed.shtml

2 https://lt.wikipedia.org/wiki/Renault_FT

3 https:/www.welt.de/img/geschichte/mobile161744904/1931624017-ci23x11-w960/ Westfront-deutscher-Sturmpanzer-Info-no.jpg

4 http://www.precision-panzer.moonfruit.com/communities/9/004/006/621/409/images/ 4586390596.jpg

5 http://i41.servimg.com/u/f41/11/01/53/00/a7v_ta10.jpg

6 https://etd.ohiolink.edu/rws_etd/document/get/osu1338500708/inline

7 http://rgaspi-458-9.germandocsinrussia.org/de/nodes/226\#page/160/mode/inspect/zoom/8

$8 \mathrm{https} / / /$ worldoftanks.ru/dcont/fb/uncommon_images/history_section/sovtanks 1/lenin. gif?MEDIA_PREFIX=/dcont $/ \mathrm{fb} /$

9 https://kam.lt/download/48066/tankai\%20lk.pdf

$10 \mathrm{http} / /$ www.bbc.com/news/uk-england-37302722

11 https://www.nzz.ch/international/europa/grafik-timeline-100-jahre-panzer-wie-sichpanzer-seit-dem-1-weltkrieg-entwickelt-haben-ld.116517

12 http://www.n-tv.de/mediathek/bilderserien/politik/Vor-100-Jahren-rollte-der-erstePanzer-in-die-Schlacht-article18646056.html

$13 \mathrm{http}: / /$ izvestia.ru/news/632711

14 http://www.epaveldas.lt/vbspi/showImage.do?id=DOC_O_86299_1\&biRecordId=7942

15 https://www.youtube.com/watch?v=zxBtow_8z00\&feature=youtu.be

$16 \mathrm{http} / / \mathrm{www} . d e l f i .1 \mathrm{t} / \mathrm{mokslas} / \mathrm{mokslas} /$ geriausi-lektuvai-amerikietiski-o-tankaivokiski.d?id $=1246150$

$17 \mathrm{http}: / /$ www.delfi.lt/news/daily/medijos-karas-propaganda/patvirtinta-vokietija-lietuvojedislokuos-tankus.d?id=72687392

$18 \mathrm{https}: / / \mathrm{www}$. youtube.com $/$ watch? $\mathrm{v}=8 \mathrm{a} 3 \mathrm{uOyOOdAo \& feature=}=$ youtu.be $\& \mathrm{t}=7 \mathrm{~m} 2 \mathrm{~s}$

$19 \mathrm{https}: / / \mathrm{www}$. youtube.com/watch? $\mathrm{v}=\mathrm{K} 2 \mathrm{mcO} 61-0 \mathrm{cY} \&$ feature=youtu.be $\& \mathrm{t}=1 \mathrm{~m} 39 \mathrm{~s}$

20 https://www.youtube.com/watch?v=k3IPA3rxpuE

21 https://www.welt.de/wirtschaft/article161078829/IS-Kaempfer-zerstoeren-dendeutschen-Panzer-Mythos.html

$22 \mathrm{http} / / / w w w . f a z . n e t / a k t u e l l / p o l i t i k / a u s l a n d /$ leopard-in-syrien-deutschlands-vorzeigepanzerunterliegt-im-kampf-dem-is-14649046.html 